\title{
A CATEGORIA MARXISTA CONTEÚDO E FORMA NA LEITURA LITERÁRIA
}

\author{
LA CATEGORÍA MARXISTA CONTENIDO Y FORMA EN LA LECTURA \\ LITERARIA
}

THE MARXIST CATEGORY CONTENT AND FORM IN LITERARY READING

\author{
Sandra Aparecida Pires FRANCO ${ }^{1}$ \\ Cyntia Graziella Guizelim GIROTTO ${ }^{2}$
}

\begin{abstract}
RESUMO: Este estudo analisa a obra Noite na taverna, de Álvares de Azevedo, em adaptação publicada em 2013. O objetivo da pesquisa foi o de perceber a relação da categoria marxista conteúdo e forma presente na obra. Para o desenvolvimento do trabalho, utilizou-se a metodologia de pesquisa bibliográfica com abordagem críticodialética. A análise permite afirmar que a relação conteúdo e forma são elementos indissociáveis em uma obra literária e favoráveis para o desenvolvimento da formação de futuros leitores.
\end{abstract}

PALAVRAS-CHAVE: Obra literária. Conteúdo e forma. Leitura literária. Categoria marxista.

RESUMEN: Este estudio analiza la obra Noche en la taberna de Álvares de Azevedo, adaptación publicada en 2013. El objetivo de la investigación fue el de percibir la relación de la categoría marxista contenido y forma presente en la obra. Para el desarrollo del trabajo se utilizó la metodología de investigación bibliográfica con abordaje crítico-dialéctico. El análisis permite afirmar que la relación contenido y forma son elementos indisociables en una obra literaria y favorable para el desarrollo de la formación de futuros lectores.

PALABRAS CLAVE: Obra literaria. Contenido y forma. Lectura literaria. Categoría marxista.

ABSTRACT: This study analyzes the work Night in the tavern of Álvares de Azevedo, adaptation published in 2013. The objective of the research was to perceive the relation of the Marxist category content and present form in the work. For the development of the work the methodology of bibliographical research with a critical-dialectic approach was used. The analysis allows to affirm that the relation content and form are

${ }^{1}$ Universidade Estadual de Londrina (UEL), Londrina - Brasil. Pós-Doc em Educação. Programa de PósGraduação em Educação da Universidade Estadual de Londrina. E-mail: sandrafranco26@ hotmail.com.

${ }^{2}$ Universidade Estadual Paulista (UNESP), Marília - Brasil. Livre Docência em Educação. Programa de Pós-Graduação em Educação da Universidade Estadual Paulista "Júlio de Mesquita Filho". E-mail: cyntia@marilia.unesp.br.

RIAEE - Revista Ibero-Americana de Estudos em Educação, Araraquara, v.12 , n.4 , p. 1972-1983, out./dez. 2017. 
indissociable elements in a literary work and favorable for the development of the formation of future readers.

KEYWORDS: Literary work. Content and form. Literary reading. Category marxist.

\section{Introdução}

A leitura de uma obra literária dos períodos do Romantismo ou do Realismo, e até mesmo anteriores, como do Trovadorismo, Humanismo ou outra escola literária, pode causar certo estranhamento nos adolescentes. Estranhamento causado principalmente pelos temas mórbidos do período ultrarromântico, como pelo vocábulo e pela linguagem diferenciada presente nessas obras diante da vivência do cotidiano do século XXI. Esses textos literários de um determinado estilo de época estão presentes, principalmente, no Ensino Médio das escolas públicas e privadas brasileiras.

No entanto, nos anos de 2014 e 2015, tivemos contato com editoras que lançaram livros literários de conteúdo clássico reeditando-as por meio de adaptação, principalmente em forma de História em Quadrinhos, procurando despertar o adolescente para o conteúdo/conhecimento de relações humanas de um determinado período histórico anterior a sua vivência.

Noite na Taverna, de Álvares de Azevedo, obra do período ultrarromântico brasileiro, conhecido como mal do século pelo seu caráter sombrio e taciturno, em sua nova edição em HQs, elaborada por Solfieri, Bertram, Gennaro, Claudius Hermann e Johann, apresenta suas narrativas macabras de outra forma. Suas narrativas são contadas em uma taverna e os leitores podem chegar ao conhecimento da obra por meio de imagens e texto escrito, feito por ilustradores. Os personagens da narrativa original apresentam-se em forma de imagem, fazendo com que o leitor consiga ao mesmo tempo em que lê, vivenciar a narrativa. O texto escrito por Azevedo em 1857 foi adaptado para uma nova forma de apresentação, que não desmerece o conteúdo e o linguajar da época em que foi escrito pela primeira vez. A forma apresentada chama a atenção das crianças e dos adolescentes pela sua criatividade, originalidade e uma forma diferente de mergulhar no século XIX. A junção do texto de Azevedo com as imagens de ilustradores desperta o desejo pela leitura. O ritmo presente, as cores, as imagens, as formas geométricas despertam para a fluidez do texto e apresentam uma obra literária em que o narrador assume por vez a voz de ator principal.

RIAEE - Revista Ibero-Americana de Estudos em Educação, Araraquara, v.12 , n.4 , p. 1972-1983, out./dez. 2017. 
Percebemos assim que forma e conteúdo, categorias marxistas, são indissociáveis nessa narrativa, apresentando um conhecimento clássico ao aluno do Ensino Fundamental e Médio.

\section{A categoria conteúdo e forma}

Para Gamboa (1998), as categorias marxistas são dialéticas, por permitirem apresentar em forma de pensamento a realidade mais concreta, ou seja, a realidade em suas múltiplas determinações. Trata-se de generalizações e processos que existem fora do pensamento, mas que ao serem conhecidas permitem apreender os conteúdos objetivos. Essas categorias não separam o homem do mundo. Muito pelo contrário, essas categorias permitem o refletir acerca da sociedade, compreendendo-a no seu todo. (MARX, 2011).

As categorias marxistas são históricas e apresentam uma função metodológica para o movimento que vai do conhecido ao desconhecido. Essas categorias podem ser todo-partes; abstrato-concreto; fenômeno-essência; causa-efeito; análise-síntese; conteúdo-forma e outras. (GAMBOA, 1998).

Em referência ao conteúdo literário, podemos afirmar, segundo Gamboa (1998), que os textos literários e filosóficos abrangem além da categoria conteúdo e forma, outra categoria primeira, a totalidade. A literatura apresenta palavras, frases, fragmentos que só adquirem significados quando se compreende o todo de um texto, que estejam em consonância com o contexto social, histórico, político, cultural. Só compreendemos um texto literário quando nos apropriamos do conjunto da obra (GOLDMANN, 1979).

Nessa mesma direção, Gamboa (1998, p. 25) afirma que:

Toda obra literária, artística ou científica é a expressão de uma visão de mundo, um fenômeno de consciência coletiva que alcança um determinado grau de clareza conceptual, sensível ou prática na consciência de um pensador, artista ou cientista.

Goldmann (1979) reafirma que considera a visão de mundo um instrumento que permite a análise contextualizada das obras filosóficas e literárias. Nesse sentido, para uma pesquisa sobre uma determinada obra literária, a questão lógico-gnoseológico que é a lógica do objeto, mais a história do objeto, ou seja, as condições históricas da produção, resultam em um novo conhecimento do objeto. Trata-se de um concreto

RIAEE - Revista Ibero-Americana de Estudos em Educação, Araraquara, v.12 , n.4 , p. 1972-1983, out./dez. 2017. 
histórico no pensamento, que só é possível conseguir quando todas as categorias marxistas coadunam para isso.

Para compreender uma obra literária precede apreender o que é arte. Vigotski (1991, p.374), referente à arte, afirmou que “[...] as formas mais desenvolvidas da arte são a chave das formas atrasadas, como a anatomia do homem o é em relação a dos macacos”. Para Vigotski (1991), a arte emprega material extraído da vida cotidiana, mas lhe dá uma configuração diferente, que produz nos indivíduos sentimentos que normalmente não são vivenciados no cotidiano.

Assim, a discussão entre conteúdo e forma é essencial para a prática pedagógica dos professores formadores de leitores. Para Lukács (apud DUARTE, 2012), o pensamento cotidiano, a ciência e a arte são formas pelas quais o psiquismo humano busca refletir o concreto. Há uma relação entre um desenvolvimento histórico e o processo de desenvolvimento da consciência, e neste entrelace está a arte. A arte para Lukács (apud DUARTE, 2012) originou-se do trabalho, como atividade coletiva de transformação da natureza e produção da vida humana. Para o autor, na arte funde-se a essência e a aparência. Revela-se ao sujeito a realidade com suas contradições intensificadas, com a dramaticidade e comicidade. A arte para Lukács (apud DUARTE, 2012) não é a reprodução fotográfica do cotidiano, mas uma forma que evidencia aspectos da realidade que tornam a arte um reflexo da vida e ao mesmo tempo uma crítica à vida.

Trata-se de expressar o conteúdo em toda a sua riqueza, buscando a perfeição da forma e do ser, levando à fusão entre forma, conteúdo e receptor.

A forma de uma obra é apenas uma expressão do conteúdo da realidade abstrata, que está presente no autor e que passará a existir no leitor, no destinatário. A obra literária é uma forma concreta que expressa um conteúdo abstrato. Conteúdo e forma devem ser analisados concomitantemente, pois são inseparáveis. (AMORA, 2004).

A forma é um elemento concreto, pois se pode ouvir ler e ver. Trata-se do elemento que fixa o conteúdo e o transmite. O conteúdo fixado é carregado pela forma. É uma realidade imaterial, enquanto que a forma é a materialidade.

O conteúdo e a forma de uma palavra, frase ou obra surgem no ato do autor, ou do artista, e se impõem na consciência do leitor. Disso deriva uma unidade. A unidade é tão perfeita que não é possível conscientizar um sem o outro. Nesse sentido, o autor é o criador e o leitor é o recriado. Conteúdo e forma são realidades concomitantes, interrelacionados e interativos. 
Para Sales (2009), a transformação da forma não significa que ocorrerá a transformação do conteúdo, porque a forma tem exigências e eficácias particulares. Uma obra de arte pode estar presente em outra época de modo imediato e concreto, desde que as relações humanas reais sejam enfocadas na própria obra.

Interessa destacar que os conceitos de conteúdo e forma são definidos de maneira diferente por diversos autores. Uns consideram conteúdo, por exemplo, em sua acepção mais superficial, como um conjunto de elementos constituintes de um objeto dado, já outros, além de deterem-se a essa significação ainda o consideram como nãodialético (CHEPTULIN, 1982). Cheptulin (1982) aponta a veracidade das críticas a tais concepções reducionistas, pois um conteúdo não pode ser visto sem o seu movimento, uma vez que os aspectos de um determinado objeto encontram-se em constante integração.

Em uma visão das leis de correlação do conteúdo e da forma, assevera o destacado autor sobre o quanto toda forma está ligada ao conteúdo. Forma e conteúdo dependem reciprocamente um do outro. O conteúdo determina a forma e as mudanças do conteúdo, e, no pensamento do indivíduo, alteram a sua forma anterior. Essa forma, por sua vez, reage sobre o conteúdo, contribuindo ou não para o seu desenvolvimento. (CHEPTULIN, 1982).

Verifica-se que o conteúdo muda rapidamente, a partir do momento em que é apropriado. A forma, por sua vez, é mais estável, mas se altera conforme o movimento. Quando há a mudança do conteúdo, esse novo conteúdo rejeita a antiga forma e força-a a mudar, transformando-se em uma nova forma, ou seja, em outro nível de desenvolvimento. Essa nova forma dá uma expansão para o conteúdo e esse começa a se desenvolver. Esse desenvolvimento do conteúdo vai ocorrendo e a forma não consegue se manter, fazendo conteúdo e forma entrarem em conflito. Essa discordância leva à rejeição da antiga forma, e ocorre a transformação da mesma; assim até o infinito. (CHEPTULIN, 1982).

$\mathrm{Na}$ literatura, quando há a rejeição de uma forma antiga, uma nova criação de forma surge. Observe as palavras do autor:

O resultado disso é que o conteúdo da nova formação material e do novo estado qualitativo, surgido em decorrência da substituição da antiga forma pela nova, é criado inteiramente no seio da antiga formação material ou do antigo estado qualitativo, e o salto em decorrência do qual foi quebrada a antiga forma e criada a nova não representa uma modificação qualitativa do conteúdo, mas unicamente

RIAEE - Revista Ibero-Americana de Estudos em Educação, Araraquara, v.12 , n.4 ,p. 1972-1983, out./dez. 2017. 
a aquisição, para ele, de uma nova forma. (CHEPTULIN, 1982, p.269).

Nesse sentido, o propósito deste estudo foi o de trabalhar com o conteúdo literário da obra Noite na Taverna de Álvares de Azevedo, na forma de HQs, analisando a fusão conteúdo, forma e receptor. Trabalhar essa literatura mostrando a presença dos seus diversos aspectos e determinações permitem ao aluno compreender o conteúdo por meio de outra forma: a HQs. Nossa hipótese é a de que essa nova forma de ler permite analisar o que está ao redor nessa sociedade do século XXI.

\section{Uma nova forma para o conteúdo da obra literária Noite na Taverna}

A recepção de uma obra de arte envolve a interação entre sujeito e objeto. Essa interação é percebida por meio da forma que se apresenta determinado conteúdo. Notamos que o artista volta-se para a forma que ele busca dar a um determinado conteúdo. Para expressar o conteúdo em toda a sua riqueza, o artista busca a perfeição da forma e, se der certo, funde forma e conteúdo. (LUKÁCS, 1966b, p.492).

Essa fusão é perceptível na obra em análise, Noite na Taverna, de Álvares de Azevedo. Nessa adaptação, os ilustradores são Márcio de Castro, Eduardo Arruda, Klayton Luz, LuCAS, Klaus Reis. O livro tem como adaptador Carlos Patati e como organizador Sílvio Alexandre. Trata-se de uma obra publicada em 2013.

Quanto à caracterização, a obra em análise pertence ao gênero História em Quadrinhos. Trata-se de uma releitura da obra Noite na Taverna, de Álvares de Azevedo, escrita em 1857, século XIX. A HQ é composta de sete histórias: Uma Noite do Século, Solfieri, Bertram, Gennaro, Claudius Hermann, Johann e o Último beijo de Amor. As principais temáticas da obra são o Amor e a Morte, comuns ao período ultrarromântico em que a melancolia e o pessimismo dominaram. Cada conto narrado em forma de HQ apresenta uma temática diferente. Uma Noite do Século tem por tema a imortalidade/mortalidade da alma; a existência/inexistência de Deus. Solfieri trata da necrofilia e da catalepsia. Bertram apresenta o amor obsessivo, o adultério, o canibalismo. Gennaro, a ingratidão, o aborto, o adultério, o suicídio. Claudius Hermann, o amor obsessivo. Johann, o incesto, assassinato. O Último beijo de Amor, a vingança e o suicídio.

Quanto aos elementos gráfico-editoriais, a obra apresenta um bom trabalho artístico. A arte foi realizada a partir de um ilustrador para cada HQ. O detalhe dos 
ambientes, as expressões fisionômicas das personagens, a tonalidade sombria e escura, transmitem o caráter macabro das histórias contadas pelos personagens/narrador. Na história de Bertram, contudo, não está presente a mesma intensidade, pois o ilustrador usa traços para as expressões fisionômicas e ambiente com tonalidades pastéis. A capa cartonada e as folhas em papel cartão demonstram uma HQ bonita e bem apresentável ao leitor. As imagens, muitas vezes, são mais expressivas que o próprio texto. Essa ausência de texto verbal é perceptível na HQ de Bertram e Claudius Hermann. Há também o uso da forma geométrica retangular para as partes narradas e os balões para a fala dos personagens. As histórias são bem encadeadas, favorecendo a leitura. Há também, na obra, informações sobre a época em que foi escrita, sobre a biografia do autor, o que favorece a compreensão da temática e a relaciona ao conteúdo pedagógico presente na escola. No entanto, a obra não apresenta paratextos, como prefácio e apresentação, os quais poderiam familiarizar o leitor com a obra antes de iniciar a leitura.

O texto possui qualidade literária e traz um conteúdo estruturante da Literatura Brasileira presente do currículo do Ensino Médio: o Romantismo, mas de uma forma diferente, fazendo com que o leitor se aproprie do novo conteúdo científico. Os contos provocam o leitor e permitem, por meio de outro suporte, que são as HQs, constituir novos sentidos. O uso de recursos de expressão, como a intertextualidade, está presente na primeira HQ: "Ou seja, Nenhuma! O amigo leu o Livro desse doido, Spinoza" (AZEVEDO, 2013, p. 8). Os personagens da primeira história se tornam narradores em outras HQ. Os ambientes são macabros e a HQ apresenta histórias verossímeis de acordo com a estética do ultrarromantismo. Em Solfieri (AZEVEDO, 2013, p. 24), por exemplo, o personagem Solfieri mostra, para os outros jovens, a grinalda em seu pescoço: "Estão vendo as flores? Murchas e secas como o crânio dela"; e, no momento em que Geórgia aparece na Taberna para a vingança: "Você!? E não é um sonho?! Você! Cinco anos depois!!! (AZEVEDO, 2013, p. 78).

A obra também explora significados simbólicos de certas imagens, como a flor para Solfieri, o navio para Bertram, a tela para Gennaro, a bebida e a taça para Claudius Hermann, a carta e o anel para Johann, a bebida e a faca na última história. As histórias são narradas de forma relativamente rápida, permitindo que o leitor vivencie alguns episódios de forma inesperada, por exemplo, quando Gennaro retorna à casa do mestre e encontra Nauza e Godofredo mortos sobre a mesa. (AZEVEDO, 2013, p. 48)

RIAEE - Revista Ibero-Americana de Estudos em Educação, Araraquara, v.12 , n.4 ,p. 1972-1983, out./dez. 2017. 
A HQ traz uma representação da vida humana afinada com a estética da segunda geração romântica, quando havia a valorização do mal do século, o sentimentalismo e o desejo pela morbidez por parte de alguns escritores: "Viva a Imortalidade da Alma! (AZEVEDO, 2013, p.10); Alma...? Ora essa, Alma! Pois eu acho que nem o vinho tem alma! Não tem...? (AZEVEDO, 2013, p. 08). Outra temática comum a esse grupo é a espiritualidade em queda: "A vadia, aqui, ainda hoje, tem um crucifixo acima da cama, e o Bispo alguns netos." (AZEVEDO, 2013, p. 15). A obra prende o leitor pela forma como é narrada, ou seja, trata-se de uma narrativa com um plano amplo, em que são apresentadas várias outras narrativas internas, não se desvinculando do conteúdo escolar. As situações narradas têm inspiração gótica-fantástica. Trata-se de uma história repleta de melancolia. Ao mesmo tempo, causa estranhamento no leitor por retratar temas mórbidos.

Pela análise da obra, podemos perceber que o receptor, por sua vez, fica atento ao conteúdo, mas o que o conduz à riqueza do conteúdo é a forma. $\mathrm{O}$ artista pode dar ao conteúdo uma forma que produza no receptor uma duplicidade, ou seja, um distanciamento em relação aos aspectos essenciais da vida dos seres humanos (DUARTE, 2012).

Só que nada é alcançado se o artista não conseguir essa transformação do conteúdo em forma e da forma em conteúdo.

Lukács (1970) discorda em dois aspetos no campo da estética: da visão idealista que separa a arte da vida real e colocam-na em outro mundo; e a visão instrumentalista em que a obra de arte tem funções práticas imediatas, centrada no conteúdo e com forma nula.

O efeito da obra de arte no indivíduo é analisado tanto por Lukács (1970) quanto por Vigostski (1999). Assinalamos aqui alguns destaques essenciais a presente discussão.

A reação estética, segundo o célebre psicólogo bielo-russo, seria aquela que "[...] encerra em si a emoção que se desenvolve em dois sentidos opostos e encontra sua destruição no ponto culminante, como uma espécie de curto-circuito". (VIGOTSKI, 1999, p.270). O autor enfatiza, portanto, que o alicerce da reação estética é a emoção e que “[...] é nessa transformação das emoções, nessa autocombustão, nessa reação explosiva que acarreta a descarga das emoções imediatamente suscitadas, que consiste a catarse da reação estética”. (VIGOTSKI, 1999, p.272). 
Lukács (1970) aborda a catarse como o momento em que o indivíduo questiona a sua vida e a si mesmo. A relação entre o indivíduo e as obras de arte, para Lukács, é sempre "[...] um passo de aproximação à omnilaterialidade do ser humano" (1966b, p. 504). A arte mostra ao ser humano o mundo como obra humana, tanto nos aspectos positivos como negativos.

\section{Considerações finais}

Quanto aos aspectos positivos da obra posta neste texto em análise, Noite na Taverna, podemos assinalar um adequado trabalho artístico. O projeto gráfico-editorial, responsável pela materialidade da obra e por sua composição de forma objetal concreta, encerra em si um conteúdo não-verbal de qualidade, o qual por sua vez cria condições motivadoras para engajar o jovem leitor em formação a um conteúdo verbal e imagético evidenciado pelo projeto estético-literário de grandeza humanizadora. Desse ponto de vista, há contribuição valorosa no processo humanizador da arte literária para que conteúdo e forma de seu psiquismo já sejam outros em suas capacidades e funções. As transformações sucessivas e inconclusas provenientes de superações revolucionárias traduzem-se em novas configurações de ser, pensar, agir e sentir do jovem leitor, diante de si mesmo, do outro e do mundo, alicerçadas por um conteúdo-forma emancipadores.

Essa análise nos permite afirmar, segundo as palavras de Lukács (1970) e Vigotski (1999), que a arte está longe de ter sua função social definida pela busca pura e simples do prazer, posto estar ligada ao processo de desenvolvimento humano, em que a mediação pode ocorrer por convívio com o cotidiano ou por estudo escolar dos conhecimentos em processos sistemáticos de ensino.

Isso nos leva a pensar que seria impossível o contato do indivíduo com qualquer bem cultural livre de interferências externas. Para nós, o contato sempre está inserido, portanto, em relações sociais. A mediação escolar, por sua vez, está embutida de interferência sistematicamente direcionada para o objetivo de fazer as apropriações culturais diversas exercerem um ato positivo para o desenvolvimento do indivíduo. (DUARTE, 2012). Essa relação se efetiva porque o leitor compreende a cultura de uma época, um diálogo entre passado e presente. Os aspectos histórico-culturais se afloram para a formação humana. Vale destacar que a obra literária tem a intenção de contaminar os traços culturais da época em que foi produzida, e por uma literatura de

RIAEE - Revista Ibero-Americana de Estudos em Educação, Araraquara, v.12 , n.4 , p. 1972-1983, out./dez. 2017. 
qualidade os alunos recriam a realidade e se apropriam da história e da cultura do homem. (ARENA, 2010).

A obra artística enriquece o indivíduo, trazendo visões históricas que se somam às experiências vividas pelo leitor. Trata-se de um confronto de velhas e novas impressões. O sujeito receptivo adquire a experiência humana e aprofunda a consciência. Eleva-se a autoconsciência humana, como mencionou Lukács em seu livro "Uma introdução à estética marxista", e um novo olhar se efetiva em seu entorno. É um novo reflexo da realidade. A obra artística torna-se um agente mediador entre a realidade reificada e o indivíduo. Nesse contexto, a arte assume um papel de esclarecimento, um reflexo que se aprofunda e se esclarece, ampliando a percepção da realidade.

Desse ponto de vista, a apropriação de qualquer conteúdo, de qualquer forma, prescinde de aprendizagem. Há destaque, todavia, ao ensino escolar, posto que ele pode criar as plenas condições para a recepção das riquezas mais elaboradas da literatura presentes na cultura humana. A obra literária pode exercer um papel desfetichizador na formação humana, pode fazer mudar no ser humano a consciência sobre a realidade social. A forma como é apresentada a literatura torna-se um legado histórico humano que pode ser socializada pela educação escolar, que é parte do processo de socialização do saber sistematizado, como transmissão e recriação de valores e conhecimentos da sociedade. (COSTA, 2014).

A literatura é vista como uma forma de expressão artística articulada ao problema do desenvolvimento da humanidade, favorecendo a formação humana. Essa preocupação é um comprometimento com a escola, com a transmissão do conhecimento mais elaborado. (COSTA, 2014).

Vale esclarecer que podemos concluir, com Duarte (2012), o quanto o ensino não substitui a leitura de um romance, conto ou poema, a audição de uma peça musical, a contemplação de um quadro, ou o assistir a uma peça teatral ou a um filme. O ensino, nessa perspectiva dialética, prepara a recepção da obra. O objetivo, todavia, não é encurtar a recepção, mas sim formar no jovem leitor as atitudes que o colocam a receber a riqueza contida na obra literária, uma vez que, para nós, todo indivíduo deve desenvolver suas próprias formas de se relacionar com as obras artístico-literárias. 


\section{REFERÊNCIAS}

AMORA, Antônio Soares. Introdução à teoria da literatura. SP: Ed. Cultrix, 2004.

ARENA, Dagoberto Buim. A literatura infantil como produção cultural e como instrumento da iniciação da criança no mundo da cultura escrita. IN: SOUZA, Renata Junqueira de. et al. Ler e compreender: estratégias de leitura. Campinas, SP: Mercado de letras, 2010.

AZEVEDO, Álvares. Noite na taverna. Adaptação de Carlos Patati. SP: Editora DCL, 2013.

CHEPTULIN, Alexandre. A dialética materialista. SP: Editora Alfa-ômega, 1982.

COSTA, Larissa Quachio. Ensino de literatura: possível humanização do indivíduo no contexto da atual sociedade, 2014. Dissertação (Mestrado em Educação Escolar). Universidade Estadual paulista "Júlio de Mesquita Filho", Faculdade de Ciências e Letras (Campus Araraquara).

DUARTE, Newton. et al. O marxismo e a questão dos conteúdos escolares. IN: Anais Eletrônicos do IX Seminário nacional de Estudos e pesquisas "História, Sociedade e Educação no Brasil”. UFPA - João Pessoa, p. 3953-3979, 2012.

DUARTE, Newton. et al. O ensino da recepção estético-literária e a formação humana. Eccos - Rev. Científica, SP, n. 28, p. 31- 48. maio/ago. 2012.

GAMBOA, Sílvio Sánchez. Epistemologia da pesquisa em educação. Tese de Doutorado. Universidade UNICAMP. SP: Campinas, 1998.

GOLDMANN, Lucien. Dialética e cultura. RJ: Paz e Terra, 1979.

LUKÁCS, Georg. Introdução a uma estética marxista. Sobre a particularidade como categoria estética. RJ: Civilização Brasileira, 1970.

LUKÁCS, Georg. Estética: la peculariedad de lo estético. v. 1. Barcelona Grijalho, 1966a.

LUKÁCS, Georg. Estética: la peculariedad de lo estético. v. 2. Barcelona Grijalho, 1966b.

MARX, Karl. Introdução - I Produção, consumo, distribuição, troca (circulação). O Método da economia política. In: Grundrisse: manuscritos econômicos de 1857-1958: esboços da crítica da economia política. Tradução Márcio Duayer e Nélio Scheider. SP: Boitempo; RJ: Ed. UFRJ, 2011.

SALES, Rafael dos Santos. A sociologia da literatura de Georg Lukács. Revista Senso Comum, n. 1, p.67-75, 2009.

VIGOSTKY, Lev Semenovitch. Psicologia da arte. SP: Martins Fontes, 1999.

RIAEE - Revista Ibero-Americana de Estudos em Educação, Araraquara, v.12 , n.4 , p. 1972-1983, out./dez. 2017. 
VIGOTSKY, Lev Semenovitch. Obras escogidas. Tomo I. Madri, Visor, 1991.

\section{Como referenciar este artigo}

FRANCO, Sandra Aparecida Pires.; GIROTTO, Cyntia Graziella Guizelim Simões. A categoria marxista conteúdo e forma na leitura literária. Revista Ibero-Americana de Estudos em Educação, Araraquara, v. 12, n. 4, p. 1972-1983, out./dez. 2017. Disponível em: <http://dx.doi.org/10.21723/riaee.v12.n4.out./dez.2017.8776>. E-ISSN: 1982-5587.

Submissão em: 13/07/2016

Aprovado em: 02/07/2017 